\title{
Mites Associated with Stored Seed Cotton and Related Products in Greece
}

\author{
C.G. Athanassiou, ${ }^{*}$ N.E. Palyvos, P.A. Eliopoulos and G.T. Papadoulis ${ }^{1}$
}

\begin{abstract}
Samples were taken during a 2-year period (Sept. 1998 to Sept. 2000) from 17 ginning mills, located in the main cotton production regions in Greece. The material was examined in order to determine the presence and relative abundance of mites in stored seed cotton and its products: cotton fiber, cottonseed and cotton gin trash. Twenty-two mite taxa were found, with the predominance of mite species on each type of stored commodity differing significantly. Fifteen taxa were recorded in seed cotton, where the most abundant species were Tyrophagus putrescentiae (Schrank) and Tarsonemus waitei Banks. In contrast, only four species were found in cotton fiber, with $T$. putrescentiae being the dominant one. Nine taxa were recorded in the cottonseed samples, where the most abundant species was by far Lepidoglyphus destructor (Schrank). Caloglyphus sp. was the most abundant species in cotton gin trash, where a total of 13 taxa were found. Most mites were found in gin trash, followed by cottonseed and seed cotton; very few mites were detected in cotton fiber.

KEY WORDS: Mites; stored cotton; cotton fiber; cottonseed; gin trash; Greece.
\end{abstract}

\section{INTRODUCTION}

Greece is the main cotton-producing country in the European Union and one of the most important cotton-producing countries in the world. More than 1.2 million tons of seed cotton are produced every year, grown on approx. 400,000 ha. The final product (seed cotton) is stored and processed in ginning mills situated all over the country. The most important product of the ginning process is cotton fiber, which represents approx. $29-32 \%$ of the initial quantity of seed cotton. Cottonseed, which constitutes more than $50 \%$ of the total, is used mainly for the production of (cottonseed) oil or for animal feed, and secondarily for seeding. The ginning process results in the production of cotton gin trash, which in some cases can exceed $10 \%$ of the total. This by-product is used mainly for fertilizer or biomass, and secondarily for animal feed.

Seed cotton, cotton fiber, cottonseed and cotton gin trash usually coexist in the ginning mill storage facilities throughout most of the year and are 'stored products'. While many studies have been published for arthropods associated with cotton in the field, very little is known about arthropods that can infest postharvest stages of cotton, despite the global distribution of cotton products (mainly cotton fiber) through international trade. Mites are considered to be one of the most serious arthropod pests of these products, not only for quantitative and qualitative losses, but also because of their ability to cause dangerous

Received Dec. 24, 2001; received in final form April 3, 2002; http://www.phytoparasitica.org posting July 16, 2002.

${ }^{1}$ Laboratory of Agricultural Zoology and Entomology, Faculty of Plant Science and Production, Agricultural University of Athens, 11855 Athens, Greece.*Author for correspondence [e-mail: xathanas@uth.gr]. 
allergies, dermatitis or respiratory problems. Our knowledge is very limited, and the available data are mainly for cottonseed $(7,9)$.

The purpose of this study was to record the mite fauna and their relative abundance in stored seed cotton and its products.

\section{MATERIALS AND METHODS}

The survey was carried out in 17 ginning mills in Greece, during a 2-year period (Sept. 1998-Sept. 2000). The mills were located in the main cotton-production regions of Greece: Thessalia, Sterea Hellas, East Macedonia and Thrace (Fig. 1). For both years most of the samples were collected from late September until late March, given that $(a)$ the European Union's regulation restricts ginning of seed cotton between September and February, and (b) most of the stored quantity is usually shelled (cotton fiber, cottonseed) or removed (cotton gin trash) by March. However, sufficient quantities of fiber, cottonseed and gin trash, and small quantities of seed cotton usually exist in ginning mills. The sampling was conducted without a specific time plan, and thus the results cannot be expressed directly as a function of time. The majority of storage facilities were large (usually $>7 \mathrm{~m}$ in height and $>300 \mathrm{~m}^{2}$ in surface) concrete or steel rectangular storerooms, with large doors and openings in order to allow direct loading of the products. The sampled products were generally stored in different, but usually large (500-5000 tons) quantities. Seed cotton and cottonseed were stored always in large bulks, while cotton fiber was packed in compressed bales (approx. 200-250 kg each), which were settled in piles. Finally, cotton gin trash was stored in bulk, usually outside or below large lodgments, close to the other facilities. Most of the samples were taken from products which were stored for more than a month. The moisture content of the samples was measured in the laboratory, using a conductance meter (Textometer DMB-X, Mahlo SA, Germany); this moisture measurer was held at $105^{\circ} \mathrm{C}$ for $3 \mathrm{~h}$ for calibration. The average percent moisture content values for each type of product are shown on Figure 2.

A total of 649 samples of $\sim 150 \mathrm{~g}$ each were taken, from seed cotton, cotton fiber, cottonseed and cotton gin trash (132, 179, 168 and 170 samples, respectively). All samples were taken by hand, from the external layers $(<1 \mathrm{~m}$ depth) of the bulks or the bales. The Berlese-Tullgren method was used to extract the mites from the samples. The device used was based on the 'modified Tullgren apparatus', as suggested by Haarlov (6). This apparatus is a unit of 36 funnels based on a tiered system of strip lighting and funnelbearing shelves. Angle iron was used as a framework and the shelves consisted of 1.9 $\mathrm{cm}$ blockboard. Alternate shelves carried four 60 -watt strip lights as a heat source and the shelves below these had 12 circular holes of $20-\mathrm{cm}$ diam to accommodate twelve 15 $\mathrm{cm}$-diam plastic funnels. The shelves bearing strip lights were fixed in position while those carrying funnels were placed on runners to enable installation and removal of samples. The samples were placed on a screen within the funnel. The heat from the light bulb desiccated the sample, forcing the mite individuals in the sample to burrow deeper into the substrate. Eventually mites fell into a screw-top collecting vial suspended underneath. In order to avoid contamination of the vials with foreign material and small particles of the product, a layer of perlite was placed on the screen. Each sample $(150 \mathrm{~g})$ was left in the funnel for 5 days. All mites were collected in vials containing $70 \%$ alcohol, $20 \%$ deionized water and $10 \%$ glycerin. Eventually, due to the continuous effect of the lights, the sample was completely dried. Then the sample was weighed, in order to express the mites found as 


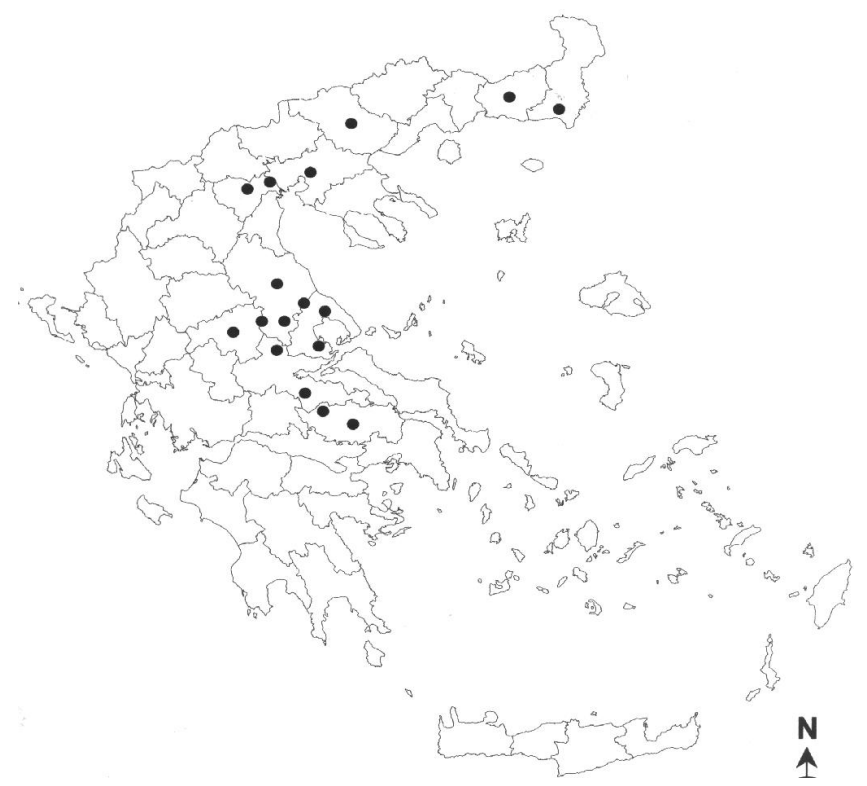

Fig. 1. Locations of ginning mills in Greece (long. 19'40-28'70; lat. 35'00-41'50) from which samples were taken.

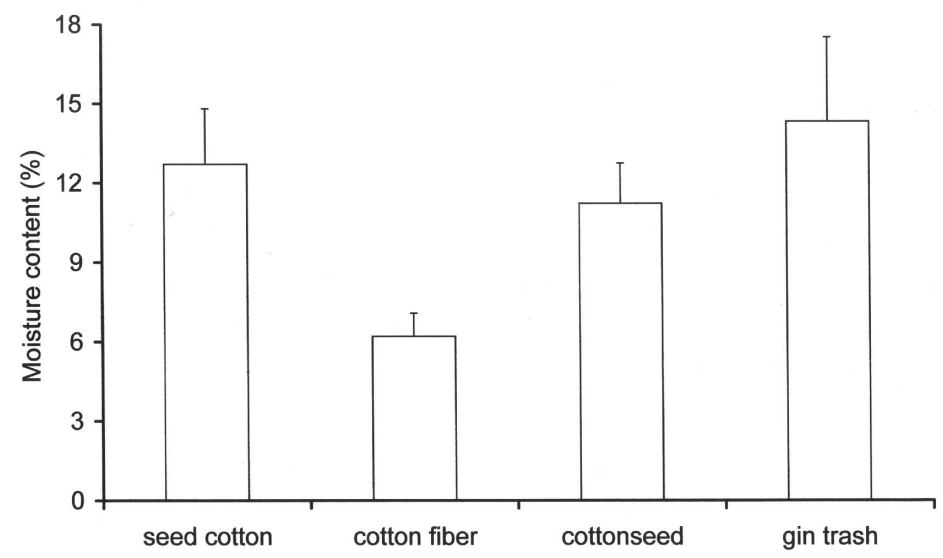

Fig. 2. Mean moisture content ( $\% \pm$ S.E.) of samples taken from the four product categories.

individuals/dry weight, which is considered the most accurate approach $(3,5)$.

For the quantitative categorization of the taxa found, the criteria Dominance and Frequency were used, as suggested by Curry (2). 'Dominance' indicates the percentage of individuals of a given taxon compared to the individuals of all taxa found. Thus, a given species (or taxon) can be classified as 'Dominant' (>5\%), 'Influent' (2-5\%), or 'Recedent' $(<2 \%)$. 'Frequency' is the percentage of samples in which the particular taxa was detected. Thus, a species can be classified as 'Constant' ( $>50 \%)$, 'Accessory' (25$50 \%)$, or 'Accidental' $(<25 \%)$. In addition, we used the criterion 'degree of infestation', which is the number of mite individuals per $10 \mathrm{~g}$ of dry weight (3). The samples were 
categorized as a, b, c, d and e, indicating $<1,1-10,1-25,26-50$ and $51-100$ mites per 10 $\mathrm{g}$ of dry weight, respectively.

\section{RESULTS}

A total of 10758 mites were found, which can be classified in 22 taxa. Some of them are known stored-product pests or phytophagous (Acarus siro, Suidasia nesbitti, Tyrophagus spp., Rhizoglyphus spp., Lepidoglyphus destructor), while others are predators (Lasioseius sp., Amblyseius barkeri, Blattisocius tarsalis, Cheyletus spp., Dendrolaelaps sp.), scavengers or mycetophagous (Kleemania plumosus, Caloglyphus sp., Tydeus sp., Tarsonemus waitei, Zygoribatula sp., Pyemotidae, Pygmephoridae, Raphignathidae, Ereynetidae) (Table 1). S. nesbitti, T. waitei, Tyrophagus similis, Lasioseius sp., Rhizoglyphus robini, Rhizoglyphus sp., A. barkeri, Dendrolaelaps sp. and Zygoribatula sp. are recorded for the first time on Greek stored products.

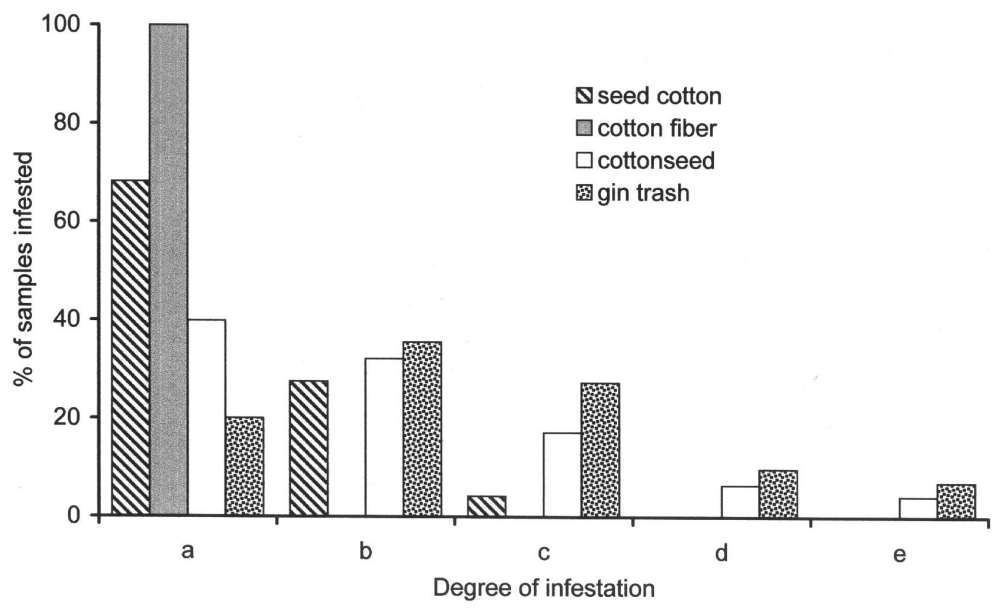

Fig. 3. Degree of mite infestation on each commodity (number of mites/10 g of dry weight; $\mathrm{a},<1$; $\mathrm{b}$, 1-10; c, 11-25; d, 26-50; e, 51-100).

Mites were found in all ginning mills examined, in $~ 41 \%$ of the total number (267) of samples. The highest percentage of mite presence was recorded in cottonseed (57.1\%), followed by cotton gin trash (49.4\%), seed cotton (40.9\%) and cotton fiber (19.9\%). Almost half of the total mite individuals were found on gin trash samples (45.8\%). Nevertheless, a significant proportion was also found in cottonseed samples (35.4\%), and secondly in seed cotton $(18.1 \%)$. Conversely, mites were rather scarce in cotton fiber $(0.7 \%)$. The highest number of taxa was recorded in the seed cotton samples (15 taxa), with only four taxa recorded in cotton fiber. All infested cotton fiber samples contained less than one mite per $10 \mathrm{~g}$ of dry weight (Fig. 3). Similarly, more than two-thirds of the seed cotton samples were classified in this category, although almost $30 \%$ of these samples were found to contain 110 individuals. On the other hand, considerably higher numbers of mites were recorded in a significant proportion of cottonseed and cotton gin trash samples. 
TABLE 1. Dominance (Dom., $\%$ of the total number of individuals), frequency (Freq., $\%$ of the total number of samples) and number of ginning mills in which each mite taxon was detected (A, accessory; Ac, accidental; C, constant; D, dominant; In, influent; R, recedent)

\begin{tabular}{|c|c|c|c|c|c|c|c|c|c|}
\hline \multirow[t]{2}{*}{ Taxa } & \multicolumn{2}{|c|}{ Seed cotton } & \multicolumn{2}{|c|}{ Cotton fiber } & \multicolumn{2}{|c|}{ Cottonseed } & \multicolumn{2}{|c|}{ Gin trash } & \multirow{2}{*}{$\begin{array}{l}\text { No. } \\
\text { of } \\
\text { mills }\end{array}$} \\
\hline & Dom. & Freq. & Dom. & Freq. & Dom. & Freq. & Dom. & Freq. & \\
\hline \multicolumn{10}{|l|}{$\begin{array}{c}\text { Astigmata } \\
\text { Acaridae }\end{array}$} \\
\hline Acarus siro L. & - & - & - & - & $0.2 \mathrm{R}$ & $4.4 \mathrm{Ac}$ & - & - & 3 \\
\hline Caloglyphus sp. & 4.5In & $18.4 \mathrm{Ac}$ & - & - & - & - & 91.9D & $28.2 \mathrm{~A}$ & 6 \\
\hline $\begin{array}{l}\text { Rhizoglyphus robini } \\
\text { Claparede }\end{array}$ & - & - & - & - & - & - & $1.3 \mathrm{R}$ & $11.1 \mathrm{Ac}$ & 2 \\
\hline Rhizoglyphus sp. & - & - & - & - & - & - & $0.6 \mathrm{R}$ & $3.7 \mathrm{Ac}$ & 1 \\
\hline $\begin{array}{l}\text { Suidasia nesbitti } \\
\text { Hughes }\end{array}$ & $<0.1 \mathrm{R}$ & $0.9 \mathrm{Ac}$ & - & - & $<0.1 \mathrm{R}$ & $1.4 \mathrm{Ac}$ & - & - & 1 \\
\hline $\begin{array}{l}\text { Tyrophagus similis } \\
\text { Volgin }\end{array}$ & $10.1 \mathrm{D}$ & $40.7 \mathrm{~A}$ & - & - & 2.9In & $18.8 \mathrm{Ac}$ & $0.3 \mathrm{R}$ & $3.1 \mathrm{Ac}$ & 6 \\
\hline $\begin{array}{l}\text { Tyrophagus } \\
\text { putrescentiae } \\
\text { (Schrank) } \\
\text { Glycyphagidae }\end{array}$ & $31.5 \mathrm{D}$ & $59.2 \mathrm{C}$ & $70.9 \mathrm{D}$ & $27.6 \mathrm{~A}$ & 4.5In & $22.2 \mathrm{Ac}$ & $1.2 \mathrm{R}$ & $10.4 \mathrm{Ac}$ & 12 \\
\hline $\begin{array}{l}\text { Lepidoglyphus } \\
\text { destructor } \\
\text { (Schrank) }\end{array}$ & $8.8 \mathrm{D}$ & $48.4 \mathrm{~A}$ & - & - & $90.4 \mathrm{D}$ & $57.9 \mathrm{C}$ & $0.4 \mathrm{R}$ & 4.7Ac & 8 \\
\hline $\begin{array}{l}\text { Cryptostigmata } \\
\text { Oribatulidae }\end{array}$ & & & & & & & & & \\
\hline $\begin{array}{l}\text { Zygoribatula sp. } \\
\text { Mesostigmata } \\
\text { Ameroseiidae }\end{array}$ & $0.3 \mathrm{R}$ & $1.1 \mathrm{Ac}$ & $12.5 \mathrm{D}$ & 9.1Ac & - & - & $<0.1 \mathrm{R}$ & $1.7 \mathrm{Ac}$ & 3 \\
\hline $\begin{array}{l}\text { Kleemania plumosus } \\
\text { (Oudemans) } \\
\text { Ascidae }\end{array}$ & $2.2 \mathrm{R}$ & $5.1 \mathrm{Ac}$ & - & - & - & - & $0.1 \mathrm{R}$ & 4.2Ac & 2 \\
\hline $\begin{array}{l}\text { Blattisocius tarsalis } \\
\text { (Berlese) }\end{array}$ & $0.4 \mathrm{R}$ & $4.7 \mathrm{Ac}$ & - & - & $0.4 \mathrm{R}$ & 7.3Ac & - & - & 4 \\
\hline $\begin{array}{l}\text { Lasioseius sp. } \\
\text { Digamasellidae }\end{array}$ & $<0.1 \mathrm{R}$ & $1.1 \mathrm{Ac}$ & - & - & - & - & - & - & 1 \\
\hline $\begin{array}{l}\text { Dendrolaelaps sp. } \\
\text { Phytoseiidae }\end{array}$ & - & - & - & - & - & - & $2.4 \mathrm{R}$ & $11.6 \mathrm{Ac}$ & 3 \\
\hline $\begin{array}{l}\text { Amblyseius barkeri } \\
\text { (Hughes) }\end{array}$ & $0.4 \mathrm{R}$ & $2.7 \mathrm{Ac}$ & - & - & - & - & - & - & 2 \\
\hline $\begin{array}{l}\text { Prostigmata } \\
\text { Cheyletidae }\end{array}$ & & & & & & & & & \\
\hline $\begin{array}{l}\text { Cheyletus eruditus } \\
\text { (Schrank) }\end{array}$ & $<0.1 \mathrm{R}$ & $2.2 \mathrm{Ac}$ & - & - & $<0.1 \mathrm{R}$ & $5.2 \mathrm{Ac}$ & - & - & 2 \\
\hline $\begin{array}{l}\text { Cheyletus } \\
\text { malaccensis } \\
\text { Oudemans }\end{array}$ & $0.9 \mathrm{R}$ & $13.1 \mathrm{Ac}$ & - & - & $1.1 \mathrm{R}$ & 14.8Ac & - & - & 4 \\
\hline Ereynetidae & - & - & - & - & - & - & $0.9 \mathrm{R}$ & $7.7 \mathrm{Ac}$ & 4 \\
\hline Pyemotidae & $0.1 \mathrm{R}$ & $3.1 \mathrm{Ac}$ & - & - & - & - & - & - & 3 \\
\hline Pygmephoridae & - & - & - & - & - & - & $<0.1 \mathrm{R}$ & $1.3 \mathrm{Ac}$ & 1 \\
\hline $\begin{array}{l}\text { Raphignathidae } \\
\text { Tarsonemidae }\end{array}$ & - & - & 4.1In & 9.1Ac & - & - & - & - & 1 \\
\hline $\begin{array}{l}\text { Tarsonemus waitei } \\
\text { Banks } \\
\text { Tydeidae }\end{array}$ & $39.9 \mathrm{D}$ & $36.3 \mathrm{~A}$ & $12.5 \mathrm{D}$ & $11.2 \mathrm{Ac}$ & $0.3 \mathrm{R}$ & 4.8Ac & $0.4 \mathrm{R}$ & 4.4Ac & 6 \\
\hline Tydeus sp. & $0.6 \mathrm{R}$ & $7.1 \mathrm{Ac}$ & - & - & - & - & $0.3 \mathrm{R}$ & $5.3 \mathrm{Ac}$ & 4 \\
\hline
\end{tabular}


The presence of mites varied markedly among the four product categories examined. Ten taxa were detected in only one product category, and seven in two categories. Most species were classified as Recedent or Accidental. Of all species found, only two $-T$. putrescentiae and T. waitei - were recorded in all types of products (Table 1). Moreover, T. putrescentiae was the most common species, given that it was found in 12 of the 17 ginning mills examined; however, it was not the most numerous species, due to its highly varying abundance on each type of product. For instance, although it is Dominant and Constant in cotton, it is Recedent and Accidental in gin trash. The most numerous species was Caloglyphus sp., given that more than $40 \%$ of the individuals found belonged to this species. It was detected mainly in gin trash, in which more than $91 \%$ of the mites were Caloglyphus sp. However, this species was recorded in only six mills. Another $33 \%$ of the total number of mites collected belonged to L. destructor. This species was found mainly in seed samples, and accounted for more than $90 \%$ of the total mite population in this type of product. Although it is also Dominant in seed cotton, this species is Recedent and Accidental in the gin trash samples, and it was not detected in cotton fiber. T. putrescentiae and $T$. waitei were the most numerous species in seed cotton, representing more than $70 \%$ of the total number of mites found in this type of product. These species are not very common in the other products. Tarsonemus waitei, for instance, is classified as Recedent and Accidental in cottonseed and gin trash samples. Finally, more than $70 \%$ of the individuals found in cotton fiber belonged to T. putrescentiae.

\section{DISCUSSION}

Although these commodities had never been examined in Greece, most of the taxa found are known stored-product mites that occur in Greek storage facilities, mainly in grain and related products $(4,5)$. Apart from the infestation itself, some of the species found are of high sanitary importance, which should be taken into account. For instance, some Acaridae and Glycyphagidae can cause serious dermatitis or asthma in humans (7). However, the main finding of this study is the varied predominance of each species on each type of product. Thus, seed cotton appears to have a notable diversity of species, some of them in relatively high numbers (in our case mainly Astigmata and T. waitei). However, the ginning procedure leads to a notable reduction in the species number. Hence, cotton fiber, the most important product of ginning, contains very few mites (in number and in species). This may be attributed to two reasons: $(a)$ cotton fiber is less likely to be infested during storage, given that moisture content of this product is almost prohibitive for mite development (Fig. 2); and (b) compared with the three other products, cotton fiber is very poor in nutritional components (such as fat, proteins, etc.). Finally, we can assume that most of the mites are destroyed or removed during the ginning process. However, in this commodity, almost one-fifth of the samples examined was found to contain mites (usually 1-3 individuals).

On the other hand, mites heavily infest cottonseed during storage. Most of the species found in this commodity are known stored-product pests. L. destructor, which was by far the most abundant species in cottonseed, is one of the most serious mite pests of stored products, given that it can develop rapidly and cause heavy losses (9). In addition, $T$. putrescentiae, the second most numerous species in seed, can develop easily in cottonseed (11).

Contrary to the case with cottonseed, most of the species found in cotton gin trash 
are mycetophagous. All species found in this commodity were classified as Recedent and Accidental, with the exception of Caloglyphus sp. Although identification was not possible at the species level, the species of this genus usually occur under conditions favoring moisture and fungal development (9). Apart from fiber and seed, the ingredients that constitute this commodity are soil and decaying plant residues, which are likely to create the aforementioned conditions. Hence, gin trash is the product type that can be considered as qualitatively different from the three others because after storage, it becomes more like a mild compost than like a stored product.

The majority of the mite species found were predators. Nevertheless, all predatory species were classified as Recedent and Accidental, and were found in a relatively small number of ginning mills. Of these species, C. malaccensis was recorded as the most abundant predator. It has been recorded recently in cottonseed in Greece (4). C. malaccensis is the most common Cheyletid in Greek storage facilities, in contrast to the situation in Central and Northern Europe, where C. eruditus appears to be the prevalent cheyletid mite of stored products $(8,12)$. This may be attributed to the fact that $T$. putrescentiae and $L$. destructor, on which $C$. malaccensis prefers to prey (10), are more numerous in Greece than Acarus siro (5), which is the preferred prey of C. eruditus (1). Our results seem to support the above assumption, given that in cottonseed $T$. putrescentiae and $L$. destructor were by far the prevalent species, and $A$. siro was rather scarce in the products examined. This is in accord with the fact that the latter species is less frequent than T. putrescentiae and L. destructor in the drier and warmer climate of Greece (5).

In conclusion, this study provided information of the mite fauna in relatively unstudied stored commodities, such as cotton and related habitats. Some of these species are likely to enter storerooms with seed cotton; however, mite occurrence is determined to a high degree by the ginning process. As a result, the composition of the fauna on each type of product is completely different. Further experimentation is required in order to evaluate the nature of the infestation, as well as mite populations as a function of time. The study is currently being conducted in the Laboratory of Agricultural Zoology and Entomology, at the Agricultural University of Athens.

\section{ACKNOWLEDGMENTS}

The authors would like to express their appreciation to Prof. C. Buchelos (Lab. of Agricultural Zoology and Entomology, Agricultural University of Athens) for his constructive criticism on this work, and thank Dr. E. Kapaxidi and Dr. E. Panou (Agricultural University of Athens) for their help in mite identification. Finally, we are grateful to T. Tsamasiotis, K. Kalogiros, E. Kyriakidou, L. Tsintarakis, and L. Sarakiotis (Hellenic Cotton Board) for their assistance in collecting samples.

\section{REFERENCES}

1. Bereen, J.M. (1984) The functional response of Cheyletus eruditus Schrank to changes in the density of its prey Acarus siro L. Acarology 6:980-986.

2. Curry, J.P. (1973) The arthropods associated with the decomposition of some common grass and weed species in the soil. Soil Biol. Biochem. 5:645-657.

3. Cusack, P.D., Evans, G.O. and Brennan, P.A. (1975) A survey of the mites of stored grain and products in the Republic of Ireland. Sci. Proc. R. Dublin Soc. Ser. B 3:273-329.

4. Eliopoulos, P.A. and Papadoulis, G.T. (2001) New records of mites (Acari: Cheyletidae) from stored products with description of a new species in Greece. Int. J. Acarol. 27:29-33.

5. Emmanouel, N.G., Buchelos, C.Th. and Dukidis, C.Th.E. (1994) A survey on the mites of stored grain in Greece. J. Stored Prod. Res. 30:175-178.

6. Haarlov, N. (1947) A new modification of the Tullgren apparatus. J. Anim. Ecol. 16:115-121. 
7. Kilpio, O. and Pirila, V. (1952) A new tyroglyphid mite causing dermatitis. Acta Dermato-Venereol. 32:197200.

8. Pulpan, J. and Verner, P.H. (1965) Control of tyroglyphoid mites in stored grain by the predatory mite Cheyletus eruditus (Schrank). Can. J. Zool. 43:417-432.

9. White, N.D.G. (1995) Insects, mites and insecticides in stored-grain ecosystems. pp. 123-167. in: Jayas, D.S., White, N.D.G. and Muir, W.E. [Eds.] Stored-Grain Ecosystems. Marcel Dekker, New York, NY.

10. Yousef, E.A., Zaher, M.A. and Kandil, M.M. (1982) Effect of prey and temperature on the development and biology of Cheyletus malaccensis Oudemans (Acari: Cheyletidae). Acarologia 25:39-42.

11. Zdarkova, E. (1969) Mites of stored food in Czechoslovakia. Proc. 2nd Int. Congress of Acarology (Budapest, Hungary), pp. 261-264.

12. Zdarkova, E. (1998) Mite fauna of stored grain in the Czech Republic. Ochr. Rostl. 34(2):49-52. 